\title{
Small Intestine Cancer pN2 TNM Finding v8
}

National Cancer Institute

\section{Source}

National Cancer Institute. Small Intestine Cancer pN2 TNM Finding v8. NCI Thesaurus.

Code C133876.

Small intestine cancer with metastasis in three or more regional lymph nodes. (from AJCC 8th Ed.) 